\title{
Correlative Study Between Nutritional Status and Remission Outcome in Childhood Acute Lymphoblastic Leukemia in Dr. Soetomo General Hospital Surabaya
}

\author{
Asma' Athifah ${ }^{1}$, Siti Nurul Hidayati ${ }^{*}$, Sulistiawati ${ }^{3}$ \\ ${ }^{1}$ Faculty of Medicine, Universitas Airlangga, Surabaya, Indonesia \\ ${ }^{2}$ Department of Pediatric, Faculty of Medicine, Universitas Airlangga, Surabaya, Indonesia - Dr. Soetomo General Hospital \\ Surabaya, Indonesia \\ ${ }^{3}$ Department of Public Health and Preventive Medicine, Faculty of Medicine, Universitas Airlangga, Surabaya, Indonesia - \\ Dr. Soetomo General Hospital Surabaya, Indonesia
}

\section{A R T I C L E I N F O}

\section{Article history:}

Received 10 April 2019

Received in revised form 27 May

2019

Accepted 12 June 2019

Available online 30 June 2019

\section{Keywords:}

Childhood acute lymphoblastic Leukemia,

Induction phase therapy outcomes, Nutritional status.

\section{*) Corresponding author:} snurul_h2004@yahoo.com

\begin{abstract}
A B S T RA C T
Introduction: The most common malignancy that is diagnosed in children is acute lymphoblastic leukemia. Undernourished children tend to have poorer long term survival. This descriptive analytic study is aimed towards analyzing the correlation between nutritional status at diagnosis and outcomes of induction phase therapy in childhood acute lymphoblastic leukemia at the Department of Pediatrics Dr. Soetomo General Hospital Surabaya in 2014.

Methods: A cross-sectional method using the medical records of patients is used in this study. The nutritional statuses of patients are calculated using weight for length/height trough curves of WHO 2006 or CDC 2000.

Results: The results show that from 45 children diagnosed with ALL, 53\% are of the age $\leq 5$ years old, with $58 \%$ males and $42 \%$ females. $13 \%$ of the patients are in the high risk group and $87 \%$ are in the standard risk group. Nutritional statuses of patients are $2 \%$ of them obese experienced remission after induction phase therapy, $56 \%$ normal with $80 \%$ of them experienced remission. $40 \%$ underweight with $89 \%$ of them experienced remission and $11 \%$ not experienced remission, $2 \%$ malnutrition and experienced remission. There is no correlation between the nutritional status of children with acute lymphoblastic leukemia with the outcome of induction phase $(p=0.798)$. Conclusion: In conclusion, there is no correlation between nutritional status and remission outcome of patients with ALL in the induction phase of therapy. However, high percentage of underweight patients shows nutrition needs special attention to improve therapy outcomes.
\end{abstract}

\section{Introduction}

Acute lymphoblastic leukemia (ALL) is a cancer that occurs due to excessive production of immature leucocytes, called lymphoblast (Leukaemia Foundation of Australia, 2015) while the nutritional status of health status generated by the balance between the needs and input of nutrients. ${ }^{14}$ During the 10-year period (19912000) acute leukemia were ranked first in pediatric malignancy at the Dr. Soetomo General Hospital Surabaya, around 59\% (524 cases) of all malignancy of these numbers are diagnosed as ALL. ${ }^{12}$ Outcomes in the induction phase can be seen from the blast of nucleated cells in the bone marrow. Remission is defined if a patient has $<5 \%$ number of blast in bone marrow aspiration. ${ }^{12}$ Prognostic factors that influence the outcome of therapy, namely: age, gender, race, number of leukocytes, obesity at diagnosis; whether leukemia starts from the B lymphocytes or T lymphocytes; if there are certain changes in chromosomes or genes of lymphocytes with cancer; Down syndrome; whether the leukemia cells found in the cerebrospinal fluid; and how fast and low white cell count after the first therapy. ${ }^{8}$ Malnutrition is also a prognostic factor that is very detrimental in children with standard risk ALL. ${ }^{10}$ Therapeutic results in patients with malnutrition worse than patients who nourished enough, more prone to infection and less able to tolerate the given treatment. ${ }^{5}$ Most children with less nutritional status are not able to meet the food needs of the body to maintain normal physiological activity of the drug because of side effects. Adequate nutrition is also necessary to maintain immune function. If a child has poor nutrition status it will be at higher risk for infection which can then extend the duration of induction, hospitalization, and even lead to death. ${ }^{3}$ Long-term survival in children 
with malnutrition status worse than children with normal nutritional status. During the continuation phase of chemotherapy undernourished child is more at risk for relapse and die and has a lower tolerance to ablative chemotherapy. It was found that the chance of dying during the initial phase of the treatment was 2.6 times lower (CI 95\%: 0.55-11.89) in normal nourished status children with ALL than in those undernourished children. The risk of death increased with the severity of undernourishment $(p=0.04) .^{7}$ The incidence rate of acute lymphoblastic leukemia in children cases, the condition of nutritional status has an important contribution in the outcome of ALL therapy, in which shows from a high mortality of patients with ALL with poor nutritional status becomes the fundamental behind this study to find the correlation between nutritional status and outcomes of remission in patients with acute lymphoblastic leukemia.

\section{Methods}

\section{Subjects}

This study was conducted in pediatric Hematology Oncology Department of Pediatrics at Dr. Soetomo General Hospital collected from patient medical record period January to Desember 2014. The technique used to take sample is total sampling with inclusion criteria all children patients with lymphoblastic leukemia that diagnosed in 2014 and exclusion criteria the document of medical records was incomplete or patient has a history of chronic disease such as tuberculosis and intestinal malabsorption.

In this study the nutritional status at the time of diagnosis which is categorized as obese, overweight, normal, thin, and very thin, calculated using weight for lenght/height trough curves of hte WHO 2006 for children $\leq 5$ years old or CDC 2000 for children $>5$ years old.

\section{Data Analysis}

The correlation beween nutritional status at diagnosis and outcomes of induction phase therapy in childhood acute lymphoblastic leukemia were analyzed with chi square using SPSS 17.0 for windows with $p<0.05$ is significantly different.

\section{Results}

The total number of patients with acute lymphoblastic leukemia was recorded in the medical record in the laboratory of the Hematology Oncology Department of Pediatrics Dr. RSUD Soetomo Surabaya in 2014 was 135 patients. There were 75 incomplete data, 14 data patients stop therapy before the induction phase is completed, and 1 data is suspected of suffering from another disease. Data that meets the inclusion criteria and can be used were 45 subjects.

\section{Characteristics of Research Sample}

Table 1. Characteristic of research sample (categories data)

\begin{tabular}{lcc}
\hline \multicolumn{1}{c}{ Variable } & Total $(\mathbf{n = 4 5})$ & Percent \\
\hline $\begin{array}{c}\text { Age at diagnosis } \\
\quad 5 \text { years old }\end{array}$ & 21 & \\
$\quad \leq 5$ years old & 24 & $56.7 \%$ \\
\hline Sex & & \\
Male & 26 & $57.8 \%$ \\
$\quad$ Female & 19 & $42.2 \%$ \\
\hline Risk group & & \\
High risk & 6 & $13.3 \%$ \\
Standard risk & 39 & $86.7 \%$ \\
\hline Nutritional status & & \\
Obesity & 1 & $2.2 \%$ \\
Normal & 25 & $55.6 \%$ \\
Underweight & 18 & $40 \%$ \\
Malnutrition & 1 & $2.2 \%$ \\
\hline Respond to & & \\
therapy & & \\
Remission & 38 & $15.6 \%$ \\
No remission & 7 & \\
\hline
\end{tabular}

Table 1 shows that in this study there are 21 children aged $>5$ years old and 24 children aged $\leq 5$ years old with average age between 3-5 years old. There are 26 male children and 19 female children. There are only six children in the high risk group from a total of 45 children. 28 children have normal nutritional status, one child obesity, and 16 underweight (2 thin, 12 very thin). Sample that experienced remission are 38 children and 7 children not experienced remission.

In table 2 presented cross data which shows the relationship between nutritional status and the response of induction phase therapy. It is seen that patients with acute lymphoblastic leukemia who have the nutritional status of obesity were in remission as many as one children; patients with normal nutrition who did not experience remission as many as 5 children and were in remission as many as 20 children; patients with underweight nutritional status that is not in remission two children and were experienced remission were 16 children; as well as the nutritional status of patients with malnutrition which did not experience remission as much as one person.

From the data processing indicates that there is no correlation between the nutritional status of children with acute lymphoblastic leukemia with the outcome of induction phase $(\mathrm{p}=0.798)$. 
Table 2. The nutritional status is based on the therapeutic response of patients

\begin{tabular}{|c|c|c|c|c|c|c|}
\hline & \multicolumn{4}{|c|}{ Nutritional status } & \multirow[t]{2}{*}{ Total } & \multirow{2}{*}{$\mathbf{P}$} \\
\hline & Obesity & Normal & Underweight & Malnutrition & & \\
\hline \multicolumn{7}{|c|}{ Respond to therapy } \\
\hline Remission & 1 & 20 & 16 & 1 & 38 & \multirow{3}{*}{0.798} \\
\hline $\begin{array}{l}\text { No } \\
\text { remission }\end{array}$ & 0 & 5 & 2 & 0 & 7 & \\
\hline Total & 1 & 25 & 18 & 1 & 45 & \\
\hline
\end{tabular}

\section{Discussion}

Leukemia is a type of cancer that is most common in children younger than 20 years in the United States. ${ }^{1}$ The most frequent type of leukemia found in children is acute lymphoblastic leukemia. ${ }^{9}$ The greatest incidence occurs at the age of 2-5 years with an average incidence of 4-4.5 cases / year / 100,000 children. In several studies it was stated that the proportion of female patients was smaller than male patients, especially after the first age of life. This proportion is more dominant at the age of 6-15 years. The ratio of men and women to ALL was 1.15 in the entire age group The ratio of men and women to ALL was 1.15 in the entire age group. ${ }^{12}$ Number of patients found higher in age group $\leq 5$ years than $>5$ years, previously study in R.D. Kandou Manado showed the same result. ${ }^{12}$

The distribution of risk group in this study together with research conducted by Widiaskara et al. in 2006 in the Pediatric ward and Clinic of Hematology-Oncology laboratory of Dr. Soetomo hospital the number of patients with standard risk 54 children $(66 \%)$ and the number of high-risk patients was 28 children (34\%). During cancer, nutrition has a decisive role in several clinical outcome measures such as response to therapy, treatment costs, and quality of life. The research that conduct in St Jude Children's Research Hospital Memphis with total 621 patients included in this analysis, $102(16.4 \%)$ were underweight at the time of diagnosis, 400 (64.4\%) were of normal weight, $64(10.3 \%)$ were at risk of overweight, and $55(8.9 \%)$ were overweight. ${ }^{4}$ While Wolley et al. $(2016)^{13}$ stated at the Pediatric Prof. dr. R.D. Kandou Manado hospital, the most number of malnutrition is $54.8 \%$, normal nutrition $32.3 \%, 3.2 \%$ overweight and $9.7 \%$ obese. Overview outcomes of remission in this study is similar to a 2006 study in the pediatric ward and clinic HematologyOncology Lab / Department Pediatric Hospital Dr. Soetomo shows that there are 33 people or as many as $48.5 \%$ were in remission after induction therapy phase, 10 people or $14.7 \%$ no remission, and 25 people or $36.8 \%$ died. ${ }^{12}$

Poor nutritional status is one of the risk factors that has a major influence on the prognosis of ALL therapy. this is due to functional impairment (eg. skeletal muscle function and imune function) which is characteristic of poor nutritional status. In addition, extremes of variation in body composition (body fatness) may be influence in drug disposition for some drugs used in therapy. ${ }^{11}$ Apparent correlation in this study presumably related to extreme of sampling variation, small sampling size, and there are many other factors that can influence the prognosis of therapy such as age, gender, intensification of therapy, white blood count at diagnosis, obesity at diagnosis; whether leukemia starts from the B lymphocytes or T lymphocytes; if there are certain changes in chromosomes or genes of lymphocytes with cancer; Down syndrome; whether the leukemia cells found in the cerebrospinal fluid; and how fast and low white cell count after the first therapy. ${ }^{8}$

\section{Conclusion}

There is no correlation between nutritional status and remission outcome of patients with ALL in the induction phase of therapy. Further research is needed to look at the factors that influence the outcome of remission induction phase therapy in children with acute lymphoblastic leukemia

\section{Conflict of Interest}

The author stated there is no conflict of interest

\section{References}

1. Barrington-Trimis, J.L., Cockburn, M., Metayer, C., Gauderman, W.J., Wiemels, J. \& McKean-Cowdin, R., 2015, 'Rising Rates of Acute Lymphoblastic Leukemia in Hispanic Children: Trends in Incidence from 1992 to 2011', Blood, vol. 125, no 19, pp. 3033-3034.

2. Brinksma, A., Roodbol, P.F., Sulkers, E., Kamps, W.A., de Bont, E.S., Boot, A.M., Burgerhof, J.G., Tamminga, R.Y. \& Tissing, W.J., 2015, 'Changes in Nutritional Status in Childhood Cancer Patients: a Prospective Cohort Study’, Clinical Nutrition, vol. 34, no.1, pp. 6673.

3. Hafiz, M.G. \& Mannan, M.A., 2008, 'Nutritional Status at Initial Presentation in Childhood Acute Lymphoblastic Leukemia and its Effect on Induction of Remission', Mymensingh Medical Journal: MMJ, vol. 17, no. 2 Suppl, pp. S46-51.

4. Hijiya, N., Panetta, J. C., Zhou, Y., Kyzer, E. P., Howard, S. C., Jeha, S., \& Sandlund, J. T. 2006. Body Mass Index Does Not Influence Pharmacokinetics or Outcome of Treatment in Children with Acute Lymphoblastic Leukemia. Blood, 108(13), pp. 3997-4002.

5. Kennedy, D.D., Tucker, K.L., Ladas, E.D., Rheingold, S.R., Blumberg, J. \& Kelly, K.M., 2004. 'Low Antioxidant Vitamin Intakes are Associated with Increases in Adverse Effects of Chemotherapy in Children with Acute Lymphoblastic Leukemia', The American Journal of Clinical Nutrition, vol. 79, no. 6, pp.1029-1036.

6. Leukaemia Foundation Australia, 2015, 'Acute Lymphoblastic Leukaemia (ALL)', [online], Available from: http://www.leukaemia. org.au/blood-cancers/leukaemias/acute-lymphoblastic-leukaemiaall, [Accessed: 29th June 2015].

7. Mejía-Aranguré, J.M., Fajardo-Gutiérrez, A., Reyes-Ruíz, N.I., Bernáldez-Ríos, R., Mejía-Domínguez, A.M., Navarrete-Navarro, S. \& del Carmen Martínez-García, M., 1999. 'Malnutrition in Childhood Lymphoblastic Leukemia: A Predictor of Early Mortality During the Induction-to-Remission Phase of the Treatment11This work was partially supported by The International Clinical Epidemiology Network (INCLEN)', Archives of medical research, vol. 30, no. 2, pp.150-153.

8. National Cancer Institute, 2015, Childhood Acute Lymphoblastic Leukemia Treatment', [online], Available from: http://www.cancer. gov/types/leukemia/patient/child-all-treatment-pdq, [Accessed: 29th June 2015].

9. Sari, T.T., Windiastuti, E., Cempako, G.R. \& Devaera, Y., 2010, 'Prognosis Leukemia Limfoblastik Akut pada Anak Obes', Sari Pediatri, vol. 7, no. 10.

10. Viana, M.B., Murao, M., Ramos, G., Oliveira, H.M., De Carvalho, R.I., De Bastos, M., Colosimo, E.A. \& Silvestrini, W.S., 1994, 'Malnutrition as a Prognostic Factor in Lymphoblastic Leukaemia: 
a Multivariate Analysis', Archives of Disease in Childhood, vol. 71, no. 4, pp. 304-310.

11. Weir, Jennifer, Reilly, John J., McColl, John H. dan Gibson, Brenda E. S. 1998. No Evidence for an Effect of Nutritional Status at Diagnosis on Prognosis in Children with Acute Lymphoblastic Leukemia. Journal of Pediatric Hematology/oncology, 20(6), 534-538.

12. Widiaskara, IM., Permono, B., Ugrasena, IGN., \& Ratwita, M., 2010, 'Luaran Pengobatan Fase Induksi Penderita Leukemia Limfoblastik Akut pada anak di Rumah Sakit Umum Dr. Soetomo Surabaya', Sari Pediatri, vol. 12, no. 2, pp. 128-134.

13. Wolley, N.G., Gunawan, S. \& Warouw, S.M., 2016. Perubahan Status Gizi pada Anak dengan Leukemia Limfoblastik Akut Selama Pengobatan. e-CliniC, vol. 4, no. 1.

14. Zebua, Y., 2014, 'Gambaran Status Gizi Balita dan Faktor-Faktor yang Mempengaruhinya di Wilayah Kecamatan Afulu Kabupaten Nias Utara', Sumatera Utara University, Medan. 